F. Knížek, V. Vokáč, F. Hartl \& M. Pavlovič, Biostratigraphically important findings of two index trilobites

\title{
BIOSTRATIGRAPHICALLY IMPORTANT FINDINGS OF TWO INDEX TRILOBITES FROM THE JINCE FORMATION (CAMBRIAN, DRUMIAN) OF THE PŘÍBRAM-JINCE BASIN (BARRANDIAN AREA, CZECH REPUBLIC)
}

\author{
František Knížek ${ }^{1}$, Václav Vokáč ${ }^{2}$, František Hartl ${ }^{3}$ \& Miroslav Pavlovič $^{4}$ \\ ${ }^{1}$ Politických vězňů 127, Př́ibram VII, 26101 \\ ${ }^{2}$ Ke Kukačce 21, Plzeň, 312 00; E-mail: Lichas@seznam.cz \\ ${ }^{3}$ Glenn Millerweg 55, 1311 RP Almere, The Netherlands \\ ${ }^{4}$ Ves Touškov 126, Stod, 33300
}

\begin{abstract}
Litavkaspis rejkovicensis Fatka, Kordule et Šnajdr from the Příbram-Jince Basin has been known to occur in a roughly $30 \mathrm{~m}$ thick eponymous Taxon-range Zone situated in the lower parts of the Jince Formation (Cambrian, Drumian), within the Eccaparadoxides pusillus Interval Zone. A unique finding of a cranidium of Litavkaspis sp. at the locality Jince-Vystrkov, described in this report, comes from the middle parts of the Paradoxides gracilis Taxon-range Zone, lying roughly $250 \mathrm{~m}$ higher than the hitherto known biostratigraphically youngest occurrence of the index taxon. Specimens of Dawsonia bohemica (Šnajdr) from the Jince Formation have been collected exclusively in about $1 \mathrm{~m}$ thick deposits of the eponymous Taxon-range Zone situated stratigraphically at the base of the Onymagnostus hybridus Interval Zone. The findings of Dawsonia cf. bohemica presented herein come from the localities Rejkovice - Potucek in the Litavkaspis rejkovicensis Taxon-range Zone, and Rejkovice - Ve žlutých in the Acadolenus snajdri Interval Zone. Their stratigraphic positions are therefore 30-50 $\mathrm{m}$ lower than the typical occurrence of Dawsonia bohemica (Śnajdr) in the eponymous Taxon-range Zone.
\end{abstract}

Keywords: Trilobita, biostratigraphy, Cambrian, Drumian, Jince Formation, Příbram-Jince Basin, Czech Republic

\section{INTRODUCTION}

Biostratigraphically important specimens of trilobites Litavkaspis sp. and Dawsonia cf. bohemica (Šnajdr) have been discovered in the Jince - Rejkovice area (Příbram-Jince Basin; Jince Formation, Cambrian, Drumian) outside the hitherto known stratigraphic range of the index species Litavkaspis rejkovicensis Fatka, Kordule et Šnajdr, 1987 and Dawsonia bohemica (Šnajdr, 1950). The figured material is housed in the paleontological collections of the Czech Geological Survey, Prague.

\section{DESCRIPTIVE PART}

Agraulidae Howell, 1937

Litavkaspis Fatka, Kordule et Šnajdr, 1987

Type species: Litavkaspis rejkovicensis Fatka, Kordule et Šnajdr, 1987; Cambrian, Drumian, Jince Formation; Rejkovice, Příbram-Jince Basin, Barrandian area, Czech Republic.

\section{Litavkaspis sp.}

(Pl. I, figs 1, 2)

For this study, we had at disposal a single, markedly dorsoventrally flattened, incomplete cranidium of a holaspid specimen (FK1268). Its morphology, especially the conspicuously vaulted frontal border, places it to the agraulid genus Litavkaspis Fatka, Kordule et Šnajdr, 1987. Due to the unfavorable preservation we leave it in the open nomenclature. This unique finding comes from the upper portion of the Jince Formation, the Paradoxides gracilis Taxon-range Zone (sensu Fatka and Szabad 2014), exposed at the locality Jince - Vystrkov, called as "Za kasárnami" (behind barracks; 49.7795619N, $13.9678108 \mathrm{E}$ ), on the north-eastern hillside of the Vystrkov Hill $(541 \mathrm{~m})$. The specimen was found in about $0.4 \mathrm{~m}$ thick layer situated in the middle levels of the greywacke-shale succession belonging 
to the Paradoxides gracilis Zone. The cranidium is preserved as an internal mould in grayish-green silty shale with a grayish-blue coating of manganese hydroxides and is partly overlain by an external mould of an incomplete exoskeleton of Ptychoparia milena (Kordule). The layer has also provided other fauna characteristic for the Paradoxides gracilis Zone: trilobites Paradoxides gracilis (Boeck) - abundant, Hydrocephalus (H.) minor (Boeck) - abundant, Hydrocephalus (Rejkocephalus) rotundatus (Barrande) - rare, Conocoryphe $(C$.) sulzeri sulzeri (Schlotheim) - abundant, Ptychoparia milena (Kordule) - abundant, and Peronopsis integra (Beyrich) - abundant; echinoderms Lichenoides priscus (Barrande) - uncommon, and Stromatocystites sp. - uncommon; brachiopods Lindinella sp. - rare; bivalved arthropods Forfexicaris sp. - very rare.

\section{Discussion to Litavkaspis Fatka, Kordule et Šnajdr, 1987}

The index taxon Litavkaspis rejkovicensis Fatka, Kordule et Šnajdr, 1987 was originally described from the lower part of the Jince Formation, Eccaparadoxides pusillus Zone, the type locality Rejkovice near Jince. Later on, Fatka and Kordule (1992) defined the new Litavkaspsis rejkovicensis Subzone within the Eccaparadoxides pusillus Zone. Its thickness was estimated to $8 \mathrm{~m}$. Subsequently, Fatka and Szabad (2014) extended the stratigraphic range of the taxon to $30 \mathrm{~m}$ at the locality Jince - Vinice and defined the Litavkaspis rejkovicensis Taxon-range Zone within the newly established Eccaparadoxides pusillus Interval Zone. The unexpected finding of Litavkaspis sp. in the middle part of the Paradoxides gracilis Zone, $250 \mathrm{~m}$ above the upper limit of the Litavkaspis rejkovicensis Zone, is thus remarkable. The precise assignment of Litavkaspis sp. at the species level and its thorough assessment require a new, wellpreserved comparative material.

Eodiscidae Raymond, 1913

Dawsonia Hartt in Dawson, 1868

Type species: Microdiscus dawsoni (Hartt in Dawson, 1868, p. 655); Cambrian, Fossil Brook Formation; New Brunswick, Canada.
Dawsonia cf. bohemica (Šnajdr, 1950)

\section{(Pl. I, figs 3-7)}

Dawsonia cf. bohemica (Šnajdr, 1950) is represented by a single pygidium and two cranidia coming from the localities Rejkovice - Potůček (brooklet; the locality No. 12 in Fatka and Kordule, 1992, and No. $12 / 2$ in Kordule 1996; 49.8078147N, 13.9568314E), and Rejkovice - Ve žlutých (the locality No. 11 in Fatka and Kordule 1992; 49.8080106N, 13.9647336E). Rejkovice - Potůček is stratigraphically situated in the Eccaparadoxides pusillus Interval Zone, whereof in the middle part of the Litavkaspis rejkovicensis Taxon-range Zone sensu Fatka and Szabad (2014). The pygidium FK1361 (Pl. I, fig. 7) found at this locality is preserved as an internal mould in grey-purple calcareous greywacke containing also fragmentary trilobite exoskeletons of Conocoryphe sp. and Germaropyge sp. Another specimen of Dawsonia cf. bohemica from Rejkovice - Potůček is represented by an external mould of an incomplete pygidium FK1362 (Pl. I, figs 3, 4) in a yellow-brown greywacke. The locality Rejkovice - Ve žlutých, corresponding biostratigraphically to the Acadolenus snajdri Taxon-range Zone, yielded an external mould of an incomplete cranidium FK1363 (Pl. I, figs 5,6$)$.

The accompanying fossil associations at both localities are rich and highly diversified. The original lists of taxa in Fatka and Kordule (1992; tab. 2) are complemented here by our further findings: Rejkovice - Potůček (grey-purple greywacke with sandy lamination and subordinate grey-brown silty shale layers): trilobites Eccaparadoxides pusillus (Barrande) - abundant, Conocoryphe cirina Šnajdr - abundant, Conocoryphe sulzeri atlanta Šnajdr - common, Litavkaspis rejkovicensis Fatka, Kordule et Šnajdr - abundant, Germaropyge sp. common, Acadoparadoxides (A.) sirokyi Snajdr rare, Hydrocephalus $(H$.) mandiki Kordule - rare, Hydrocephalus (Rejkocephalus) knizeki Kordule rare, Skreiaspis spinosa (Pompeckj) - rare, Novocatharia havliceki (Šnajdr) - very rare, Solenopleurina tyrovicensis Růžička - very rare, Ptychoparia sp. - very rare, Ptychoparioides chlupaci Kordule - very rare, Phalacroma bibullatum (Barrande) - very rare, Peronopsis cf. fallax (Linnarson) - very rare, Condylopyge cf. rex (Barrande) - 


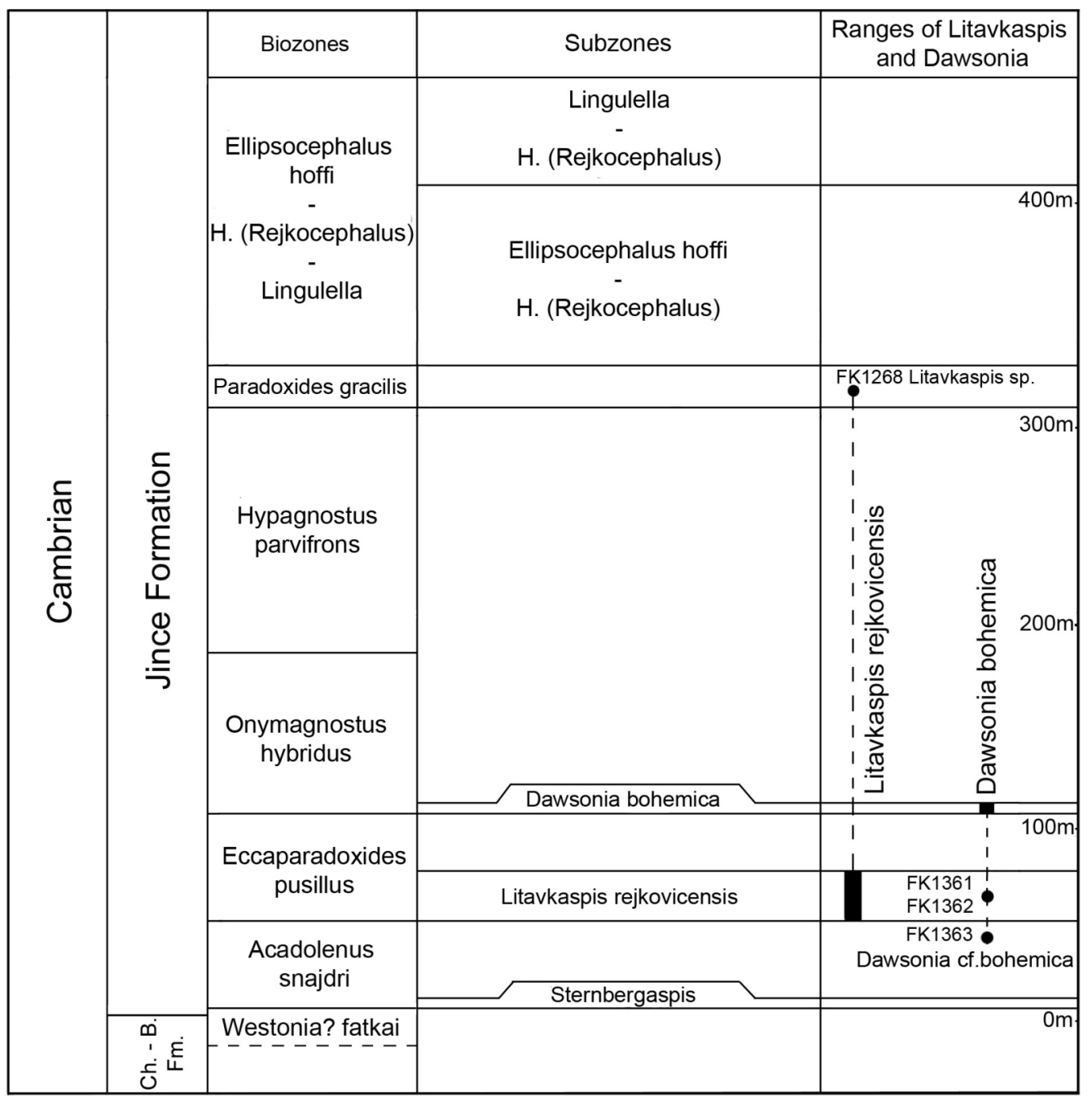

Figure 1. Range-chart of the index trilobite taxa Litavkaspis rejkovicensis Fatka, Kordule et Šnajdr and Dawsonia bohemica (ঙ̌najdr) accros the Jince Formation (Cambrian, Drumian) in the Príbram-Jince Basin, with the designated unusual biostratigraphic positions of the open-nomenclature specimens of Litavkaspis sp. and Dawsonia cf. bohemica (Šnajdr) discussed in this report. The biostratigraphic division of the uppermost ChumavaBaština Formation (Ch.-B. Fm.) and the Jince Formation has been modified after Fatka and Szabad (2014). The thickness scale corresponds to the stratotype section of the Jince Formation in the Litavka River Valley (Fatka and Szabad, 2014, fig. 9).

very rare, and Dawsonia cf. bohemica (Šnajdr) very rare; echinoderms Decacystis sp. - rare, Etoctenocystis sp. - rare, Ceratocystis sp. - rare, Stromatocystites sp. - rare, Asturicystis havliceki Fatka et Kordule - very rare, and Cigara sp. very rare; brachiopods Brahimorthis pompeckiana Havlíček - very rare, Westonia bohemica (Koliha) rare, and Glyptacrothele bohemica (Barrande) rare; Hyolitha div. gen. et sp. - rare; Algae indet. (remnants) - rare.

Rejkovice - Ve žlutých (variegated greywacke to silty shale): trilobites Eccaparadoxides pusillus (Barrande) - abundant, Conocoryphe cirina Šnajdr abundant, Novocatharia havliceki (Šnajdr) uncommon, Acadolenus snajdri Fatka et Kordule uncommon, Skreiaspis spinosa (Pompeckj) - common, Jincella prantli (Růžička) - very rare, Lobo- cephalina emmrichi (Barrande) - rare, Ctenocephalus coronatus (Barrande) - very rare, Ellipsocephalus vetustus (Pompeckj, 1895) - common, Ptychoparia sp. - rare, Ptychoparioides sp. - rare, and Dawsonia cf. bohemica (Śnajdr) - very rare; echinoderms Decacystis sp. - rare, and Acanthocystites sp. - rare.

\section{Discussion to Dawsonia cf. bohemica (Šnajdr, 1950)}

The stratigraphic range of the eodiscid taxon Dawsonia bohemica (Šnajdr, 1950) was refined by Šnaj$\mathrm{dr}$ (1958). He extended it into the uppermost layers of the Eccaparadoxides pusillus Zone. At that time, this level was only known from a locality next to the hillside Vinice near Jince, exposed in the riverbed of the Litavka River. Later on, Fatka 


\section{Plate I}

and Kordule (1992) noticed a rich occurence of the taxon at their locality No. 19, situated at the base of the Onymagnostus hybridus Taxon-range Zone. The stratigraphically narrow (about $1 \mathrm{~m}$ ) succession with an abundant eodiscid material was denoted at the same time as the horizont with Dawsonia bohemica. Fatka and Kordule (1992, fig. 2, designated with a question mark) reported a questionable ocurrence of this eodiscid taxon from the locality Rejkovice - Ve žlutých (No. 11) belonging to the Acadolenus snajdri Subzone, within the Eccaparadoxides pusillus Zone. Fatka et al. (2004) placed the taxon Dawsonia cf. bohemica (Šnajdr) to the Acadolenus snajdri and Litavkaspis rejkovicensis subzones. Recently, Fatka and Szabad (2014) defined the Dawsonia bohemica Taxonrange Zone coinciding with the range of the original horizon with Dawsonia bohemica, i.e., the $1 \mathrm{~m}$ thick succession in the stratotype section of the hill slope Vinice, near Jince (No. 19 of Fatka and Kordule 1992). The new material, which was found ca. 30-50 m below the base of the Dawsonia bohemica Taxon-range Zone, confirms the occurence of Dawsonia cf. bohemica (Šnajdr) in the Litavkaspis rejkovicensis and Acadolenus snajdri Taxon-range Zones, as was already proposed by Fatka and Kordule (1992), and Fatka et al. (2004).

\section{CONCLUSION}

The new findings of trilobite specimens from the Jince Formation, figured and described herein as Litavkaspis sp. and Dawsonia cf. bohemica (Šnajdr), are stratigraphically important. They come from the strata behind the currently known stratigraphic ranges of the index taxa Litavkaspis rej- kovicensis and Dawsonia bohemica in the PříbramJince Basin. However, their precise stratigraphic significance needs an exact taxonomical assignment. This task will require gathering of additional, much better preserved study material.

\section{ACKNOWLEDGEMENT}

We would like to express our thanks to Oldřich Fatka and Lukáš Laibl (both from Charles University, Prague), and Petr Budil (Czech Geological Survey, Prague) for their constructive criticism and suggestions to the previous drafts of this contribution. We also thank P. Budil and P. Kraft (Charles University, Prague) for their editorial help with the article.

\section{REFERENCES}

Dawson, J. W. 1868. Acadian Geology: The geological structure, organic remains, and mineral resources of Nova Scotia, New Brunswick, and Prince Edward Island. 694 pp. MacMillan and Co., London.

Fatka, O. , Kordule, V. 1992. New fossil sites in the Jince Formation (Middle Cambrian, Bohemia). Věstník Českého geologického ústavu 67(1), 47-60.

Fatka, O., Kordule, V., Szabad, M. 2004. Stratigraphic distribution of Cambrian fossil in the Příbram-Jince Basin (Barrandian area, Czech Republic). Senckenbergiana lethaea 84(1/2), 369-384.

Fatka, O., Kordule, V., Šnajdr, M. 1987. Litavkaspis, a new Middle Cambrian trilobite genus. Věstník Ústředního ústavu geologického 62(3), 179-181.

Plate I. Biostratigraphically significant specimens from the Jince Formation. 1, 2 - Litavkaspis sp.: Paradoxides gracilis Taxon-range Zone, Jince - Vystrkov, "Za kasárnami" (behind barracks); 1) incomplete cranidium, internal mould in association with incomplete specimens of Ptychoparia milena (Kordule), FK1268, scale bar $10 \mathrm{~mm}$; 2) dtto, detail, FK1268, scale bar 5 mm. 3, 4, 7 - Dawsonia cf. bohemica (Šnajdr, 1950): Litavkaspis rejkovicensis Taxon-range Zone, Rejkovice - Potůček (brooklet); 3) incomplete cranidium, external mould, FK1362, scale bar $2 \mathrm{~mm}$; 4) incomplete cranidium, external mould, FK1362, scale bar $2 \mathrm{~mm}$; 7) incomplete pygidium, internal mould, FK1361, scale bar $1.5 \mathrm{~mm}$. 5, 6 - Dawsonia cf. bohemica (Šnajdr, 1950): Acadolenus snajdri Taxon-range Zone, Rejkovice - Ve žlutých; 5) incomplete cranidium, imprint of external exoskeleton surface (negative counterpart), FK1363, scale bar $2 \mathrm{~mm}$; 6) incomplete cranidium, imprint of external exoskeleton surface (negative counterpart), FK1363, scale bar 2 mm. 8-10 - Litavkaspis rejkovicensis Fatka, Kordule et Šnajdr, 1987: incomplete cranidia, internal moulds, Litavkaspis rejkovicensis Taxon-range Zone, Rejkovice - Potůček (brooklet); 8) VV3276/ 512 , scale bar $3 \mathrm{~mm}$; 9) VV3269/512, scale bar $3 \mathrm{~mm}$; 10) VV3270/512, scale bar $3 \mathrm{~mm}$. All specimens were coated with ammonium chloride (except figs 3,5 ); photographs taken by M. Pavlovič. 
Fatka, O., Szabad, M. 2014. Cambrian biostratigraphy in the Příbram-Jince Basin (Barrandian area, Czech Republic). Bulletin of Geosciences $89(2), 413-429$.

Howell, B. F. 1937. Cambrian Centropleura vermontensis fauna of northwestern Vermont. Geological Society of America Bulletin 48, 11471210.

Kordule, V. 1996. Význam některých méně známých fosiliferních lokalit pro stratigrafii jineckého souvrství v českém středním kambriu.
Věstník Českého geologického ústavu 71(1), 3747.

Raymond, P. E. 1913. On the genera of the Eodiscidae. Ottawa Naturalist 27, 101-106.

Šnajdr, M. 1950. Aculeodiscus nov. gen. ze středočeského středního kambria (Trilobitae). Sborník Ústředního ústavu geologického, oddíl paleontologický 17, 201-206.

Šnajdr, M. 1958. Trilobiti českého středního kambria. Rozpravy Ústředního ústavu geologického $24,1-280$. 